\title{
Woody Cover and Grass Production in a Mesquite Savanna: Geospatial Relationships and Precipitation
}

\author{
R. J. Ansley, ${ }^{1}$ M. Mirik, ${ }^{2}$ C. B. Heaton, ${ }^{3}$ and X. B. Wu ${ }^{4}$ \\ ${ }^{1}$ Professor and ${ }^{2}$ Senior Research Scientist, Texas A ${ }^{\prime} M$ AgriLife Research, Vernon, TX 76384, USA; ${ }^{3}$ Graduate Research Assistant and ${ }^{4}$ Professor, Dept of \\ Ecosystem Science and Management, Texas AઐM University, College Station, TX 77843, USA.
}

\begin{abstract}
Woody plant effects on grass production at specific points in some rangeland savannas may be a function of numerous surrounding woody plants with lateral roots that extend into those patches of grass. This study determined the effects of increasing zones of honey mesquite (Prosopis glandulosa Torr.) influence on the production of three perennial grass types $\left(\mathrm{C}_{4}\right.$ shortgrasses, $\mathrm{C}_{3}$ midgrasses, and $\mathrm{C}_{4}$ midgrasses) at specific points in gaps between mesquite trees in each of five years. Mesquite canopy cover was determined by geospatial analysis of aerial images for progressively increasing zones $(0-5,0-10,0-15$, and $0-$ $20 \mathrm{~m}$ radius) surrounding each grass production point. The woody cover/grass production relationships were mostly linear for $\mathrm{C}_{4}$ shortgrasses and $\mathrm{C}_{3}$ midgrasses, and mostly a declining exponential curve for $\mathrm{C}_{4}$ midgrasses in all canopy zones, indicating that $\mathrm{C}_{4}$ midgrasses were most sensitive to increasing mesquite cover, especially at covers $>30 \%$. The relationship between mesquite cover and $\mathrm{C}_{4}$ shortgrass production was strongest (i.e., highest $r^{2}$ ) when the smallest woody cover zones (0-5 and 0-10 $\mathrm{m})$ were included. In contrast, the relationship between cover and $\mathrm{C}_{4}$ midgrass production was strongest when the largest zones (0-15 and 0-20 m) were included. These differences were attributed to an inability of $\mathrm{C}_{4}$ midgrasses to persist in smaller intercanopy gaps resulting from increases in mesquite density and infilling. Annual precipitation and $\mathrm{C}_{3}$ annual grass invasions played a large role in determining the woody cover/grass production relationship for each grass type. This study illustrates the complexity involved in quantifying woody cover/grass production relationships in savanna ecosystems. Maintaining productive stands of $\mathrm{C}_{4}$ midgrasses may be facilitated by maintaining woody cover below $30 \%$ threshold levels and possibly by limiting grazing during episodic high rainfall events in midsummer when this grass type becomes somewhat decoupled from woody cover effects.
\end{abstract}

Key Words: brush invasion, competition, lateral roots, Prosopis glandulosa, rangeland, remote sensing

\section{INTRODUCTION}

Woody plant expansion into savanna and grassland systems over the past century has been documented throughout the world, including the United States (Grover and Musick 1990; Schlesinger et al. 1990; Archer et al. 1995; Van Auken 2000). Woody plant (i.e., "brush") encroachment into grasslands often leads to reduced grass production due to competition for water, light, and other resources (Scholes and Archer 1997). While there appears to be a clear relationship between grass production and cover of evergreen woody species, such as Juniperus spp. (McPherson and Wright 1990; Dye et al. 1995; Miller et al. 2000), the relationship between grass production and cover of some deciduous woody species such as mesquite (Prosopis spp.) is more variable. Many studies have documented increases in grass production following mesquite treatments (McDaniel et al. 1982; Bedunah and Sosebee 1984; Laxson et al. 1997), but there is no clear agreement as to the shape of the functional curve between grass production and woody cover (Scanlan 1992; Ansley et al. 2004; Teague et al. 2008;

\footnotetext{
This research was supported by a grant from the E. Paul and Helen Buck Waggoner Foundation and a National Science Foundation Graduate Research Fellowship Award to $\mathrm{C}$. Heaton.

Correspondence: Dr. Jim Ansley, P0 Box 1658, 11708 Hwy 70 South, Vernon, TX 76384, USA. Email: jansley@ag.tamu.edu
}

Manuscript received 30 May 2013; manuscript accepted 26 August 2013.

(c) 2013 The Society for Range Management
Mohamed et al. 2011). Potential sources of this variability may include shrub size and density (Laxson et al. 1997), amount and timing of precipitation (Gibbens et al. 1986), type of grass species (Scifres et al. 1982; Ansley et al. 2004), degree of herbaceous degradation prior to treatments that reduce woody cover (Ansley et al. 2006; Teague et al. 2008), microclimate variations caused by woody canopies (Villegas et al. 2010a; 2010b), and the lateral expanse and depth of woody plant roots in gaps between woody plant canopies (Schenk and Jackson 2002).

Most studies that have documented woody cover/grass production relationships have used a set of clipping points to estimate grass biomass and transect lines to determine woody canopy cover for a particular area. However, little information is available concerning how the geospatial pattern of surrounding woody canopy cover relates to production of different grass species at specific points on the landscape. This has particular significance in savanna ecosystems where the dominant woody species may have extensive lateral roots that can radiate considerable distances laterally from the tree center. In these systems, grass growth within any gap between woody plants could be affected by immediately adjacent trees as well as more distal trees that have extended lateral roots into that gap (Heitschmidt et al. 1988; Ansley et al. 1990; Scholes and Archer 1997; Schenk and Jackson 2002). Collectively, we might refer to this assemblage of trees as the "zone of influence" of woody plant cover on any grass production point (GPP) within an intercanopy gap. Use of remote sensing techniques to 
map woody cover within a particular zone of influence may be a useful tool in understanding these relationships (Mohamed et al. 2011; Mirik and Ansley 2012a; 2012b).

The optimum "zone of influence" that best describes the relationship between woody cover and grass production at any GPP may differ among grass species (Ansley et al. 2004). Stateand-transition models have indicated that as woody encroachment and canopy cover increases, typically the grass community degrades and shifts from tallgrasses to midgrasses to shortgrasses (Archer 1990). In some deciduous savannas, there also occurs a shift from $\mathrm{C}_{4}$ tall- or midgrasses to $\mathrm{C}_{3}$ midgrasses that grow mostly in early spring, before leaves of woody species emerge, and essentially avoid the shading effects of the woody overstory (Hicks et al. 1990; Ansley et al. 2010). Because taller $\mathrm{C}_{4}$ grasses appear to be more sensitive than $\mathrm{C}_{3}$ midgrasses or $\mathrm{C}_{4}$ shortgrasses to increasing woody cover, we might assume that in a mixed grass savanna that is being invaded by woody plants, the taller $\mathrm{C}_{4}$ grasses would be found in more open areas that have not yet experienced extreme woody plant encroachment that allows only $\mathrm{C}_{3}$ midgrasses or $\mathrm{C}_{4}$ shortgrasses to persist. Because of this, we might also expect that a greater amount of land area around a GPP (i.e., a greater "zone of influence") would be needed to accurately assess woody cover/ grass production relationships in taller $\mathrm{C}_{4}$ grasses. Geospatial analysis would aid in our understanding of this dynamic.

In addition to these factors, annual precipitation can affect the relationship between woody cover and grass production, but this has not been well documented in very many semiarid savanna ecosystems (McPherson and Wright 1990; Teague et al. 2008). Other transient factors such as episodic outbreaks of $\mathrm{C}_{3}$ annual grasses or certain forb species may also affect the woody cover/grass production relationship in certain years (Ansley et al. 2010).

Our objective was to quantify the effects of the geospatial arrangement of honey mesquite (Prosopis glandulosa Torr.) canopy cover on the production of three perennial grass types $\left(\mathrm{C}_{4}\right.$ shortgrasses, $\mathrm{C}_{3}$ midgrasses, and $\mathrm{C}_{4}$ midgrasses) growing on similar soils in a mixed-grass mesquite woodland.

\section{METHODS}

\section{Study Area}

The research site is located on a 260-ha area of native rangeland $37 \mathrm{~km}$ southwest of Vernon, Texas (lat $33^{\circ} 53^{\prime} \mathrm{N}$, long $99^{\circ} 21^{\prime} \mathrm{W}$; elev. $380 \mathrm{~m}$ ) in north central Texas. The climate of the area is continental and semiarid. Mean annual precipitation is $65.2 \mathrm{~cm}$; peak rainfall periods are April/May and September/October. Mean annual air temperature is $17^{\circ} \mathrm{C}$ (NOAA-NCDC 2011). Soils are fine, mixed, thermic Typic Paleustolls of the Tillman and Wichita series that are clay loams, 3-4 m deep, underlain by sandstone/shale parent material (USDA-NRCS 2011). Soil texture and depth are uniform across the site. Vegetation is dominated by a woody overstory of honey mesquite and a mixture of $\mathrm{C}_{3}$ and $\mathrm{C}_{4}$ perennial grasses. Dominant $\mathrm{C}_{4}$ midgrass species are silver bluestem (Bothriochloa laguroides [DC.] Herter subsp. torreyana [Steud.]), vinemesquite (Panicum obtusum H.B.K.), and sideoats grama (Bouteloua curtipendula [Michx.] Torr.). The primary $\mathrm{C}_{3}$ midgrass species is Texas wintergrass (Nassella leucotricha [Trin. and Rupr.] Pohl). The dominant $\mathrm{C}_{4}$ shortgrass species is buffalograss (Buchloe dactyloides [Nutt.] Engelm.) (USDA-NRCS 2009). In some years the site experiences outbreaks of the $\mathrm{C}_{3}$ annual grass, Japanese brome (Bromus japonicus Thunb. ex Murray), within perennial grass patches. Cattle had grazed the pasture at a moderate, continuous stocking rate of about $12 \mathrm{ha} \cdot \mathrm{cow}^{-1}\left(30 \mathrm{ac} \cdot \mathrm{cow}^{-1}\right)$ since 1960.

Mesquite on the site consisted of a variety of canopy cover levels (range $5 \%$ to $80 \%$ ) and tree heights (range $2 \mathrm{~m}$ to $5 \mathrm{~m}$ ), resulting from various mesquite-specific aerial herbicide treatments applied 10, 20, or 35 years earlier in 3.4 ha $(84 \times 400 \mathrm{~m})$ blocks (see Ansley et al. 2004). None of the herbicide treatments negatively affected the grass community; thus, any differences in grass production during the 10- to 35-year period after treatment were assumed to be due to variations in mesquite cover and/or cattle grazing.

Within this mixture of mesquite cover types, we randomly located 24 plots; each plot consisted of one 3-4-m-diameter patch of each of three perennial grass types $\left(\mathrm{C}_{4}\right.$ shortgrasses, $\mathrm{C}_{3}$ midgrasses, and $\mathrm{C}_{4}$ midgrasses) located in gaps between mesquite trees (intercanopy gap). Each patch was defined as a "grass production point" or GPP and was included in the study if the target grass type occupied at least $80 \%$ by visual estimate of the basal cover of all grass species within the GPP. The grass species used to represent the $\mathrm{C}_{4}$ shortgrass and $\mathrm{C}_{3}$ midgrass types were buffalograss and Texas wintergrass, respectively. These are considered the most common representatives of these two grass types in the southern Great Plains. The $\mathrm{C}_{4}$ midgrass GPPs were less common on the study site and it was not possible to limit this grass type to a single species. Therefore GPPs in this grass type were either silver bluestem or vine mesquite. These two species are fairly representative, in terms of annual production, of most of the $\mathrm{C}_{4}$ midgrass species that are found in the region.

\section{Grass Production Measurements}

To quantify grass production at each GPP, a $2 \times 3 \mathrm{~m}$ portion of the patch was mowed to $3 \mathrm{~cm}$ in height in the winter months (January-early February) prior to each growing season, and a 1 -m-wide $\times 2$-m-long $\times 1.5$-m-tall cage made of galvanized sheep fence panel was placed in the middle of the mowed area to exclude livestock grazing. During 1998-2002, all herbaceous standing mass was clipped within two different $0.25 \mathrm{~m}^{2}$ areas in each cage and sorted by species. Material for each target grass type was retained, oven-dried at $60^{\circ} \mathrm{C}$ and weighed. The other material was discarded. To estimate maximum annual production for each grass type, a "bracketing” strategy was employed in which one of the two quadrats was clipped during the middle of the usual peak growing period for each grass type and the other was clipped toward the end. For the $\mathrm{C}_{3}$ midgrass type, the two clippings were in late spring (May) and midsummer (July). For the $\mathrm{C}_{4}$ midgrass and $\mathrm{C}_{4}$ shortgrass types, the two clippings were in midsummer (July) and late summer (September). The greater value of the two clippings was used for the study.

In some years, $\mathrm{C}_{3}$ annual grasses occurred within the GPPs and usually expressed peak growth in midspring (late April to May). Therefore, $\mathrm{C}_{3}$ annual grass production was quantified by 
clipping all $\mathrm{C}_{3}$ annual grass plants that occurred within each $\mathrm{C}_{3}$ midgrass quadrat during the first clipping in late spring (May). This was used as a proxy to represent $C_{3}$ annual grass production for the entire system, because there did not appear to be any strong association of annual grasses with any particular GPP (by visual estimate). Moreover, the physical structure of the annual grasses was too deteriorated to adequately represent maximum production for that year by the time the $\mathrm{C}_{4}$ grass type GPPs were first clipped in July.

\section{Mesquite Nearest Neighbor Measurements}

The nearest mesquite tree in each of four equal quadrants radiating from the center of each GPP was measured for the following variables: distance from the center of each GPP to tree canopy edge, tree height, canopy diameter (at widest point), number of basal stems per tree and diameter of the largest basal stem. The values for the four trees were then averaged.

\section{Mesquite Cover Measurements}

Color infrared aerial photographs of the site were taken on September 2, 2000, at a nominal scale of 1:5000. The images were scanned at $0.5-\mathrm{m}$ resolution and georegistered using ArcGIS 10 (ESRI Inc, 2010). Prior to taking the aerial photographs, two 2 -m-long $\times 6$-cm-diameter white PVC poles were placed adjacent to each other laterally across the top of the clip cage in each GPP. These poles were then visually located on the images, and the midpoint of the poles was established as the georeferenced GPP using ArcView. Mesquite canopy cover was classified on the images using the unsupervised classification procedure in ArcView GIS Image Analysis extension (Heaton et al. 2003). Given that $>98 \%$ of the woody canopy cover consisted of mesquite, it was assumed that all woody vegetation on the images was mesquite.

Subsequent to image classification, four circular zones of increasing land area or "zones of influence" $(0-5,0-10,0-15$, and $0-20 \mathrm{~m}$ ) were created using the "buffer" function in ArcView at each GPP location with the clip cage being the center of each zone of influence (hereafter "zone") (Fig. 1). Percent mesquite canopy cover within each of these zones was determined by dividing the canopy area by the total land area within each zone. Because the annual increase in mesquite cover is usually small (Ansley et al. 2001), and because the site experienced drought during most of the study period, the mesquite cover values that were determined from the 2000 images were applied to all five years of grass production data (1998-2002). Precipitation data were obtained from a nearby NOAA weather station (NOAA-NCDC 2011).

\section{Data Analysis}

A completely randomized analysis using PROC GLM for unequal replicates was used to compare production of each grass type when averaged over all GPPs in each year and over the five years. LSD was used to separate means at $P \leq 0.05$. These statistical analyses were performed with SAS software package version 9.1 (SAS 2002). Means and standard errors (SEs) were determined for mesquite nearest neighbor data that were measured at study initiation, but no formal statistical analyses were conducted.
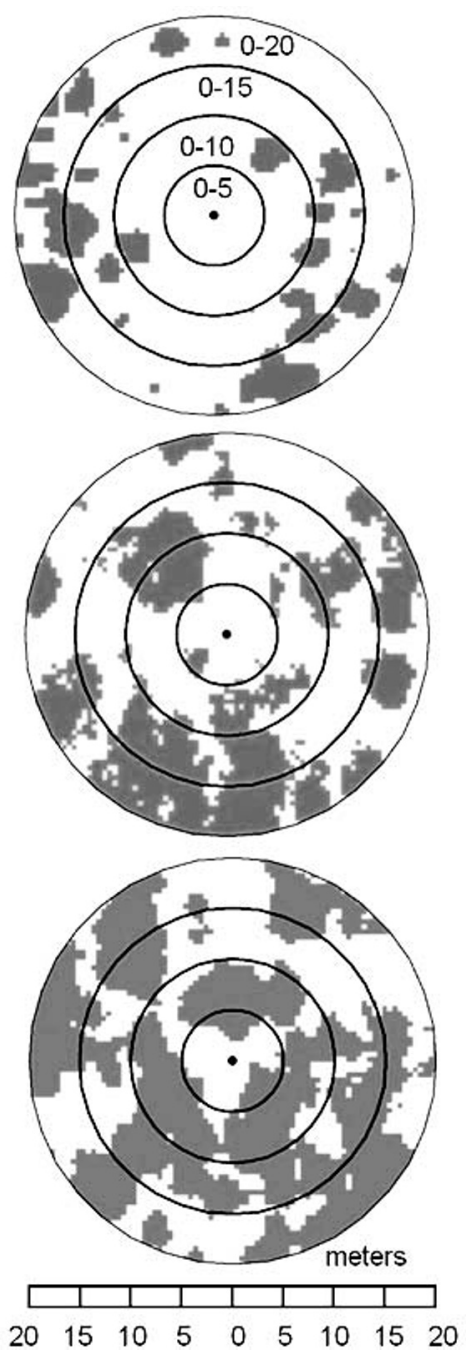

Figure 1. Illustration of the four geospatial zones of influence surrounding a grass production point (GPP; black dot) within a gap between mesquite trees. Gray shapes represent mesquite canopies.

For mesquite cover and grass production relationships, bestfit linear or curvilinear regressions were determined between mesquite cover in each zone of influence and production at each GPP in each year using SigmaPlot and SigmaStat software version 11.0 (Systat Software Inc, 2009). Four regression functions were used, ranging from simplest to most complex: (1) linear $\left(y=y_{0}+a x\right)$; (2) exponential decay, single, twoparameter $\left(y=a e^{-b x}\right)$; (3) exponential decay, single, threeparameter $\left(y=y_{0}+a e^{-b x}\right)$; and (4) logistic, four-parameter,

$$
y=y_{0}+\frac{a}{1+\left(\frac{x}{x_{0}}\right)^{b}}
$$

where $y_{0}$ is the intercept, and $a, b$, and $x_{0}$ are coefficients. The Durbin-Watson test for independent distribution, the Kolmogorov-Smirnov (K-S) test for normality, and the Constant Variance test were performed on all regressions. A regression between mesquite cover and grass production was considered statistically significant if $P \leq 0.05$. However, a regression was not considered robust or "strong" unless $r^{2}>0.50$ and/or $P<0.0005$. 


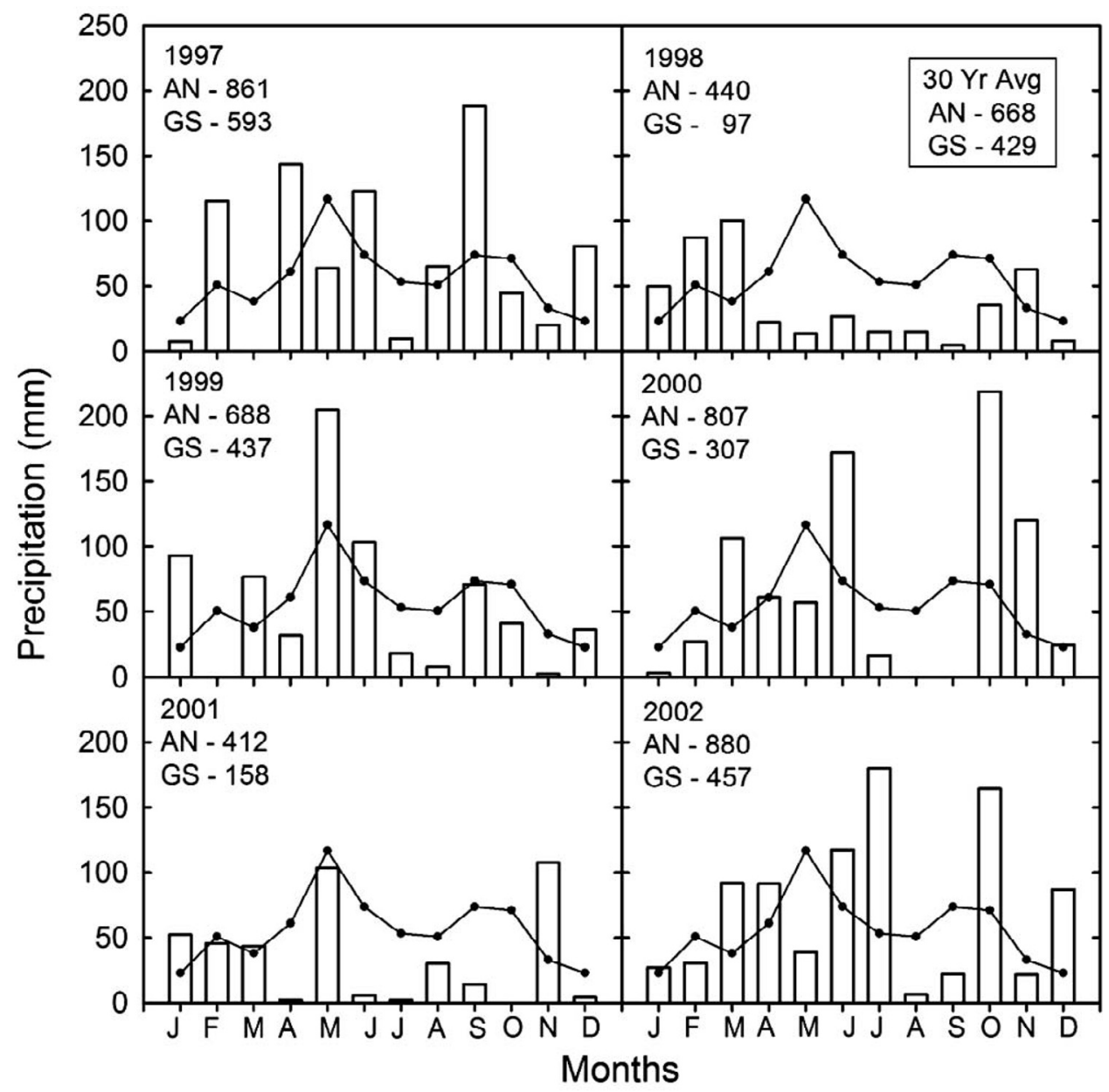

Figure 2. Monthly precipitation (bars) and 30-yr average for each month (line) at the site from 1997-2002. Annual (AN) and growing season (GS; AprilSeptember) totals are shown for each year compared to the 30-yr averages (inset panel).

Selection of the most appropriate regression model for each grass type, zone, and year was determined by first selecting the most simple model (linear), then including more complex models if they (1) appeared by visual estimation to be a better fit for the data, and (2) appeared to be a biologically plausible trend line. If a more complex curve was selected, then Akaike's Information Criterion (AIC) was used to determine whether the more complex model was more likely a better fit than the simpler model (Akaike 1973; Bozdogan 1987). A modified version of the AIC for smaller data sets, termed $\mathrm{AIC}_{\mathrm{c}}$, was employed in this study (Motulski and Christopoulos 2003; Burnham and Anderson 2004). An $\mathrm{AIC}_{\mathrm{c}}$ value was determined for each regression model using the equation,

$$
\mathrm{AIC}_{\mathrm{C}}=\mathrm{N} \dot{\sin }\left(\frac{R S S}{N}\right)+2 K+\frac{2 K(K+1)}{N-K-1}
$$

where $N$ is the number of data points, $K$ is the number of parameters fit by the regression plus one, RSS is the residual sum of squares of the regression and ' $\mathrm{n}$ ' is the natural logarithm (Burnham and Anderson 2002). Because AIC is derived from information theory, the $\mathrm{AIC}_{\mathrm{c}}$ method cannot be used to test statistical significance, only the relative likelihood between two or more models (Motulski and Christopoulos
2003). The model with the lower $\mathrm{AIC}_{\mathrm{c}}$ value was considered to be more likely to be correct and was displayed in the figures.

\section{RESULTS}

\section{Precipitation}

The study was preceded by a year of above-average precipitation in 1997 (Fig. 2). This was followed by a very dry growing season (April-September) in 1998, an average year in 1999, and two years (2000 and 2001) with below-average precipitation during the growing season. The final year (2002) had above-average precipitation in June followed by three times the average precipitation in July. Each year from 1998-2002 had average to above-average precipitation over the first quarter (January-March) that would normally favor $\mathrm{C}_{3}$ grass growth. The years 1999, 2000, and 2002 had average to above-average precipitation during the late-spring or summer period that would normally favor $\mathrm{C}_{4}$ grass growth.

\section{Mesquite Structure and Gap Size}

At study initiation, the average distance of the nearest mesquite canopy edge to the center of each GPP appeared 


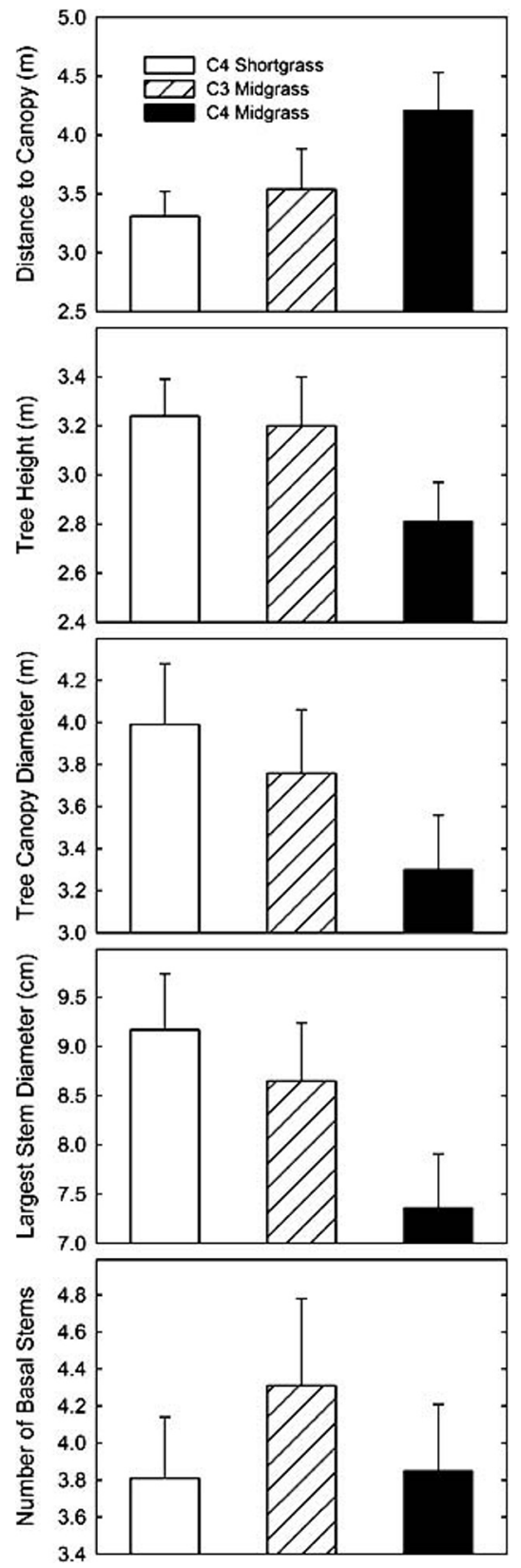

Figure 3. Mesquite canopy and stem characteristics of nearest 4 trees to each grass production point at study initiation, 1998. Vertical lines are \pm 1 standard error $(n=24-29)$. Means with similar letters are not significantly different at $P \leq 0.05$.

(i.e., no $\mathrm{SE}$ bar overlap) to be larger in $\mathrm{C}_{4}$ midgrass than in $\mathrm{C}_{3}$ midgrass and $\mathrm{C}_{4}$ shortgrass patches (Fig. 3). Conversely, mesquite height, canopy diameter, and basal stem diameter appeared to be larger (no SE bar overlap) in $\mathrm{C}_{4}$ shortgrass than $\mathrm{C}_{4}$ midgrass patches, with $\mathrm{C}_{3}$ midgrasses intermediate. There was no difference (i.e., SE bars overlapped) in mesquite basal stem number among grass types. Percent mesquite canopy cover was similar among all grass types within the 0 15 and $0-20 \mathrm{~m}$ zones around each grass type, averaging between $41-44 \%$ (Fig. 4). In the smallest zone, $0-5 \mathrm{~m}$, the percent mesquite cover was lower $(P \leq 0.05)$ in the $C_{4}$ midgrass type than in the other two types.

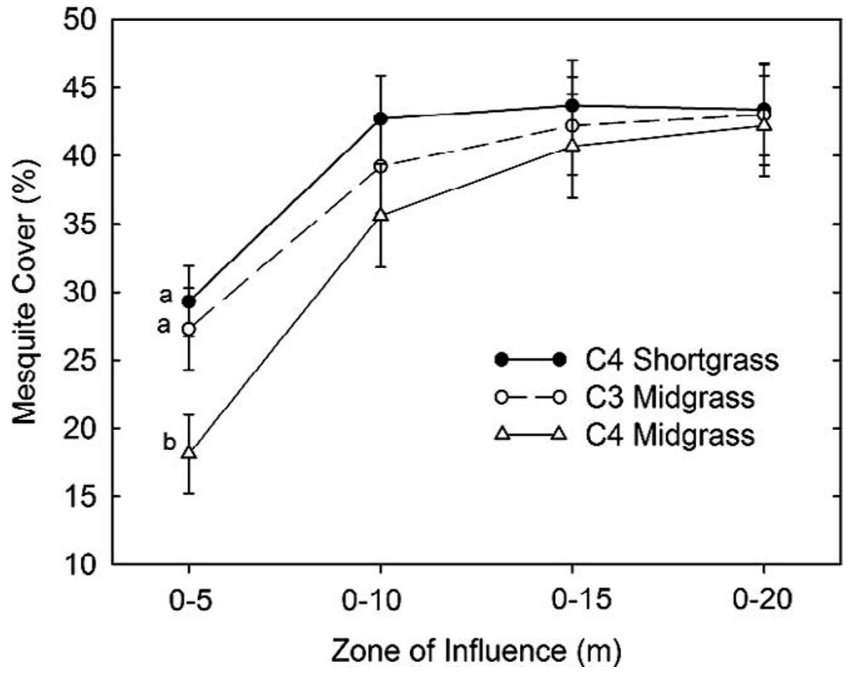

Figure 4. Percent mesquite canopy within each land area zone of influence around GPPs of the three perennial grass types at study initiation, 1998. Vertical lines are \pm 1 standard error $(n=24-29)$. Means with similar letters are not significantly different at $P \leq 0.05$.

\section{Grass Production Each Year}

When the production of all GPPs was averaged within each grass type each year, production was generally greatest to least in $\mathrm{C}_{4}$ midgrasses, $\mathrm{C}_{3}$ midgrasses, and $\mathrm{C}_{4}$ shortgrasses, respectively (Fig. 5). The exceptions were in 1998 and 1999 when there was no difference $(P \leq 0.05)$ between $\mathrm{C}_{4}$ and $\mathrm{C}_{3}$ midgrasses, and 2000 when there was no difference $(P \leq 0.05)$ between $\mathrm{C}_{3}$ midgrasses and $\mathrm{C}_{4}$ shortgrasses. Maximum annual production of any of the perennial grass types occurred in 2002 with $\mathrm{C}_{4}$ midgrasses $\left(359 \mathrm{~g} \cdot \mathrm{m}^{-2}\right)$. Averaged over five years, $\mathrm{C}_{4}$ midgrass production was nearly twice as great as $\mathrm{C}_{3}$ midgrass production and over four times greater than $\mathrm{C}_{4}$ shortgrass production; $\mathrm{C}_{3}$ midgrass production was over twice that of $\mathrm{C}_{4}$ shortgrasses. Production of $\mathrm{C}_{3}$ annual grasses varied among years and was greater than any of the perennial grass types in 1999 and 2001. In 2001, the extreme drought year, $\mathrm{C}_{3}$ annual grass production was over two times greater than the combined production of all three perennial grass types (124 vs. $\left.46 \mathrm{~g} \cdot \mathrm{m}^{-2}\right)$.

\section{Mesquite Cover Vs. Grass Production}

Significant $(P \leq 0.05)$ linear relationships were found between mesquite cover and $\mathrm{C}_{4}$ shortgrass production in all zones in 1998, with a slightly higher $r^{2}$ value in the $0-10 \mathrm{~m}$ zone (Figs. $6 \mathrm{~A}-6 \mathrm{D})$. In the next two years, significant $(P \leq 0.05)$ linear relationships were found only in the $0-5 \mathrm{~m}$ zone in 1999 , and the $0-5$ and $0-10 \mathrm{~m}$ zones in 2000 (Figs. 6E, 6I, and 6J). In the extreme drought (2001) and extreme wet (2002) years, the mesquite cover/ $\mathrm{C}_{4}$ shortgrass production relationship was significant $(P \leq 0.05)$ in all zones, but had higher $r^{2}$ values in the three largest zones in each year. In most instances, the relationship was linear with the exception of the two largest zones in 2001, when the relationship exhibited a decreasing exponential curve (Figs. $6 \mathrm{O}$ and $6 \mathrm{P}$ ).

Significant $(P \leq 0.05)$ relationships between mesquite cover and $\mathrm{C}_{3}$ midgrass production were found in all zones in 1998, with the greatest $r^{2}$ value in the $0-10 \mathrm{~m}$ zone (Figs. 7A-7D). In 


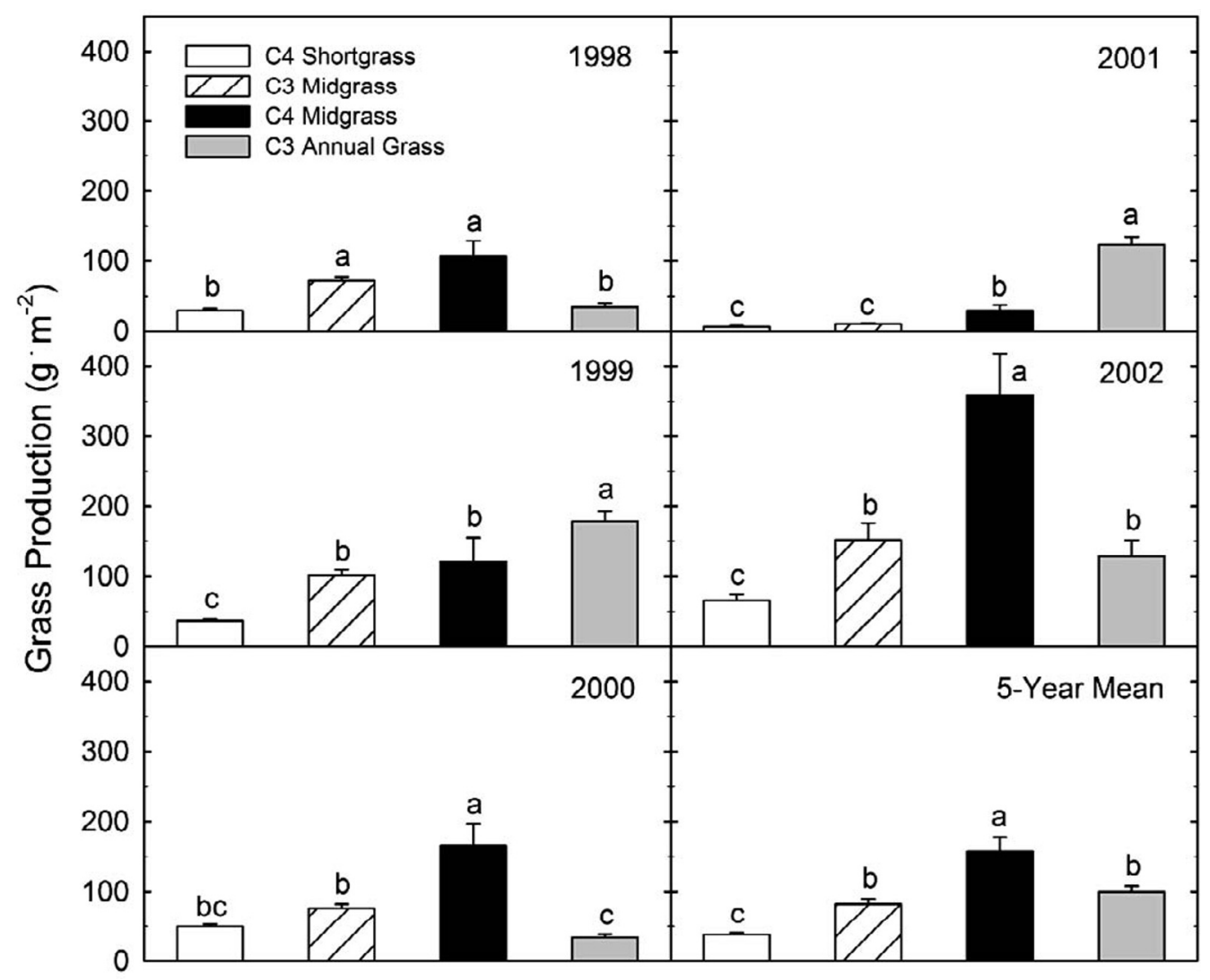

Figure 5. Mean annual production of each grass type in each year (1998-2002) and averaged over five years. Vertical lines are \pm 1 standard error. Means within each panel followed by similar letters are not significant at $P \leq 0.05$ ( $n=23$ for $\mathrm{C}_{4}$ shortgrass, 25 for $\mathrm{C}_{3}$ midgrass, 23 for $\mathrm{C}_{4}$ midgrass, and 24 for $\mathrm{C}_{3}$ annual grass).

the next two years, the relationship had higher $r^{2}$ values in the three larger zones than in the $0-5 \mathrm{~m}$ zone with the greatest $r^{2}$ value in the $0-15 \mathrm{~m}$ zone (Figs. $7 \mathrm{E}-7 \mathrm{~L}$ ). During the extreme drought year in 2001, there was no relation between mesquite cover and $\mathrm{C}_{3}$ midgrass production (Figs. $7 \mathrm{M}-7 \mathrm{P}$ ). However, in the extreme wet year, 2002, this relationship exhibited a significant $(P \leq 0.05)$ decreasing slope in all zones, with the greatest $r^{2}$ value in the $0-20 \mathrm{~m}$ zone (Figs. 7Q-7T). With the exception of the $0-20 \mathrm{~m}$ zone in 2002, all cover/grass production relationships for the $\mathrm{C}_{3}$ midgrass type were linear.

Significant $(P \leq 0.05)$ curvilinear relationships were found between mesquite cover and $\mathrm{C}_{4}$ midgrass production in all years and zones, with the exception of the year 2001, and were expressed either as a decreasing exponential or decreasing logistic curve (Fig. 8). Within each year from 1998-2000, the relationship had the greatest $r^{2}$ values in the $0-15$ or $0-20 \mathrm{~m}$ zones (Figs. 8D, 8H, and 8K). During the extreme drought (2001) and extreme wet (2002) years, the $r^{2}$ values were not as high as found in the previous three years due to either very low growth (2001) or greater variability among points (2002) (Figs. $8 \mathrm{M}-8 \mathrm{~T})$.

There were more instances where there was a strong relationship (defined as $r^{2}>0.50$ ) between mesquite cover and $\mathrm{C}_{4}$ midgrass production (11) than there were with the other perennial grass types ( 2 and 4 ) (Figs. 6-8). Regarding $C_{3}$ annual grass production, there was little to no relationship between mesquite cover and this grass type in any of the years or mesquite zones (not shown).

Differences in the strength of the mesquite cover/grass production relationship occurred as the size of the zone of influence changed, and the nature of these differences varied among grass types. For example, when averaged over all five years, the $r^{2}$ value of the mesquite cover/grass relationship in $\mathrm{C}_{4}$ midgrasses progressively increased with increasing zone of influence size (Table 1). Conversely, in $\mathrm{C}_{4}$ shortgrasses, the 5 -yr $P$-value average increased (i.e., became less significant) with increasing zone size. These trends were even more apparent when only the first three years (1998-2000), which had more typical rainfall patterns, were included. The 3 -yr mean $r^{2}$ values progressively decreased with increasing zone size in $\mathrm{C}_{4}$ shortgrasses, just the opposite of $\mathrm{C}_{4}$ midgrass responses. No clear trends were apparent for either $\mathrm{C}_{3}$ midgrasses or $\mathrm{C}_{3}$ annual grasses.

\section{Mesquite Distance and Grass Production}

The relationship between mean distance from grass production point to the four nearest mesquite trees and grass production was significant $(P \leq 0.05)$ in three of the five years for $C_{4}$ shortgrasses and $\mathrm{C}_{3}$ midgrasses, but in only one year for $\mathrm{C}_{4}$ midgrasses (Table 2). The slope of each equation was positive, indicating that as distance from the grass plot to the trees increased, so did grass production. However, the $r^{2}$ values were 


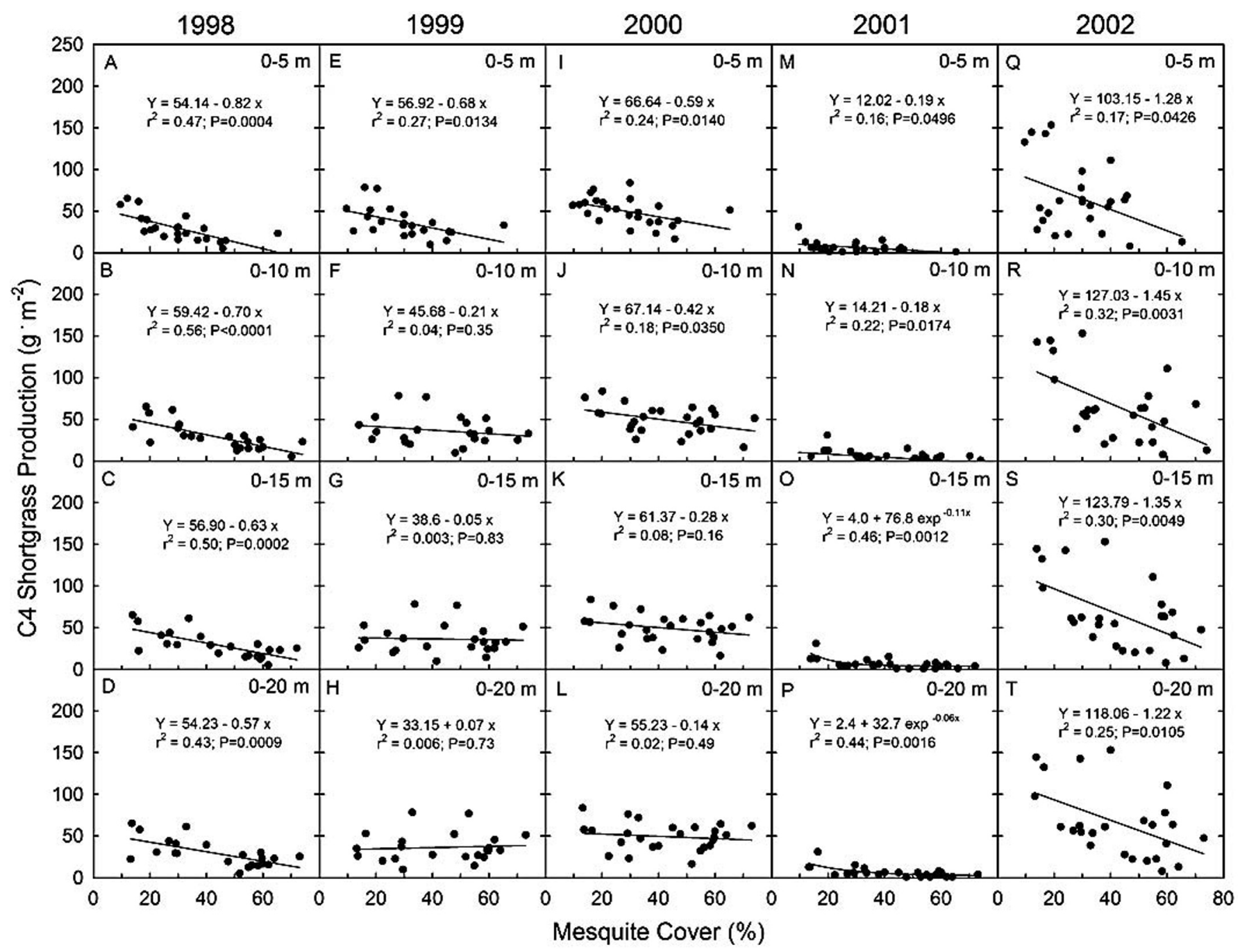

Figure 6. Regression between $\mathrm{C}_{4}$ shortgrass production and mesquite percent canopy cover in four land area zones surrounding the grass production point, 1998-2002. Each panel is labeled A-T according to a specific year and land area zone.

very low, ranging from 0.21 to 0.36 in the seven significant regressions.

\section{DISCUSSION}

Our study showed how several factors cause variation in the woody cover/grass production relationship on similar soils within a single honey mesquite woodland/savanna. These factors include the geospatial distribution of woody plant cover, the type of grass, annual precipitation patterns, and effects of an invasive annual grass. In the following sections, we will address each of these factors. Because annual grass production was closely aligned with precipitation, these two factors will be discussed together.

\section{Zone of Influence}

In most cases, the relationship between woody cover and grass production changed with increasing or decreasing zone of influence. This was found for each of the three perennial grass types. In many instances, the goodness-of-fit of the regression either progressively increased or decreased with increasing size of the zone of influence. In $\mathrm{C}_{4}$ midgrasses, the trend was toward a better fit with increasing zone size, whereas the opposite was true for $\mathrm{C}_{4}$ shortgrasses. The $\mathrm{C}_{3}$ midgrasses had an intermediate response with greatest regression fit occurring in the middle zones, $0-10$ and $0-15 \mathrm{~m}$. There were exceptions to this trend, especially in the extreme drought year of 2001. More consistent trends were found in the first three years compared to the last two years.

Because the intercanopy gap size was larger at the $\mathrm{C}_{4}$ midgrass sites, we would expect that the mesquite cover/grass production relationship for this grass type would require a larger "zone of influence" to better describe the mesquite surrounding the GPP than would be required by the other grass types $\left(\mathrm{C}_{3}\right.$ midgrasses, $\mathrm{C}_{4}$ shortgrasses) that were able to persist in smaller intercanopy gaps. The distance-to-nearest tree measure did not yield close relationships with grass production in any grass type (Table 2). However, the fact that there were fewer significant $(P<0.05)$ relationships between distance-tonearest tree and $\mathrm{C}_{4}$ midgrass production compared to the other grass types provides additional evidence that $\mathrm{C}_{4}$ midgrass 


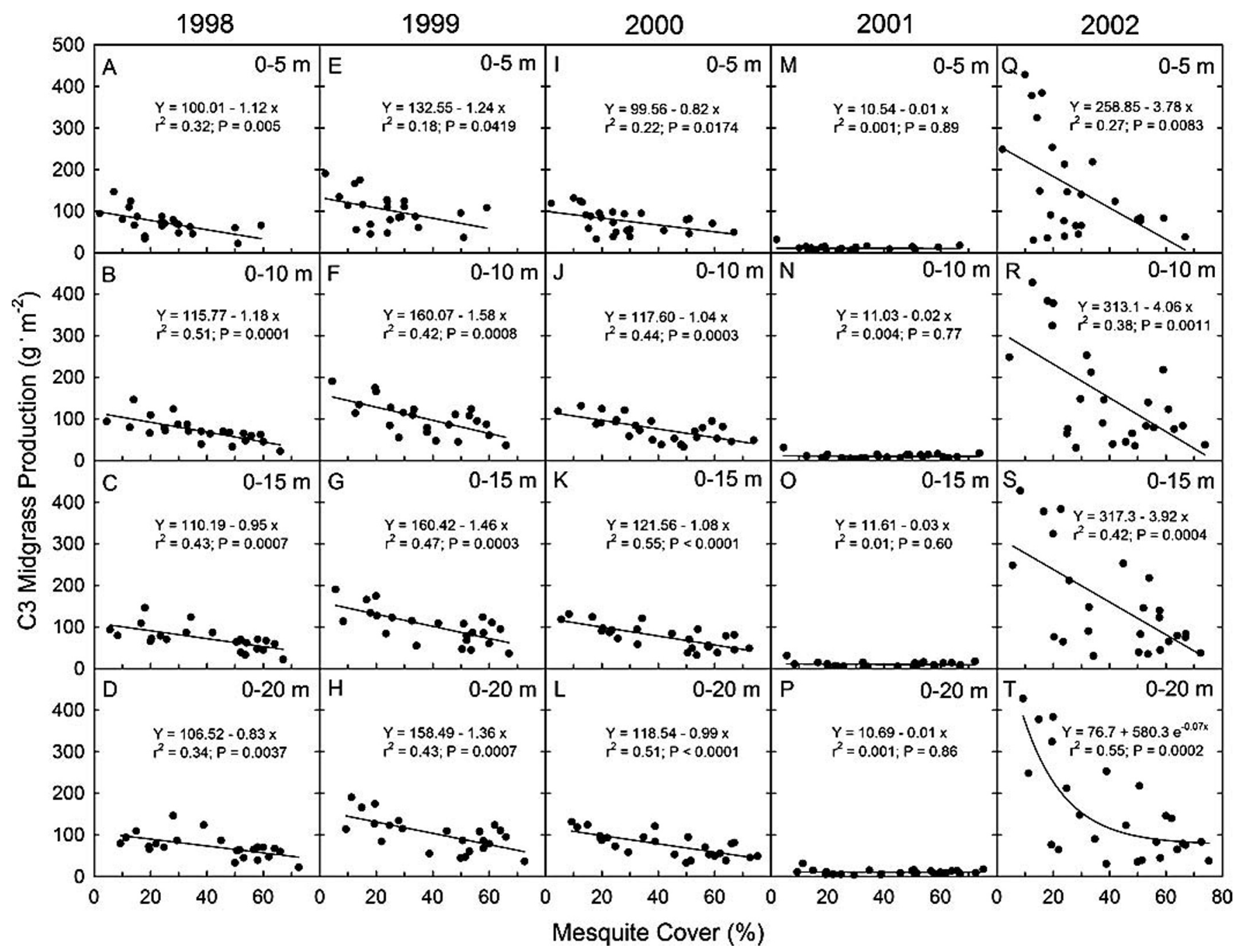

Figure 7. Regression between $\mathrm{C}_{3}$ midgrass production and mesquite percent canopy cover in four land area zones surrounding the grass production point, 1998-2002. Each panel is labeled A-T according to a specific year and land area zone.

production was influenced by more than just the nearest trees. Mesquite has extensive lateral roots, and it is possible that roots from distant mesquite trees impacted $\mathrm{C}_{4}$ midgrass production. Some studies have shown that the bulk of mesquite lateral roots that extend beyond the tree canopy are located between 0.5 and $1.0 \mathrm{~m}$ below the soil surface instead of nearer the soil surface (Heitschmidt et al. 1988). Roots at this depth would likely have a greater effect on grasses with deeper root systems, such as $\mathrm{C}_{4}$ midgrasses, than the more shallow-rooted $\mathrm{C}_{4}$ shortgrasses. The $\mathrm{C}_{3}$ midgrass (Texas wintergrass) roots would be deeper than $\mathrm{C}_{4}$ shortgrasses and would encounter mesquite lateral roots. However, the mechanism of how this grass type copes with mesquite is based more on phenologyrelated avoidance than direct root competition.

Other factors such as shading by mesquite canopies and canopy effects on microclimate may have affected grass production as well (Villegas et al. 2010a; 2010b). Shading effects would have been most critical in the morning, but not midday, because all of the GPP sites were in intercanopy patches and were not beneath the mesquite canopies. During summer months, most of the daily leaf stomatal conductance and photosynthesis of mesquite occurs in the morning (1-3 h postsunrise) before air temperatures exceed $40^{\circ} \mathrm{C}$ (Ansley et al. $1990 ; 1998)$. If the same trend is true for grass species, it is possible that mesquite shading in the mornings impacted grass photosynthesis on high canopy cover sites. In contrast, the possible cooling effect of proximity to mesquite canopies (Villegas et al. 2010b; Royer et al. 2012) may have lessened moisture stress on GPPs in the higher density mesquite areas. However, this did not offset the negative effects of higher mesquite canopy cover and presumably greater competition for water via lateral roots on grass production.

\section{Grass Type}

Of the three perennial grass types evaluated, $\mathrm{C}_{4}$ midgrasses were more negatively affected by increasing mesquite cover than were $\mathrm{C}_{3}$ midgrasses and $\mathrm{C}_{4}$ shortgrasses. The $\mathrm{C}_{4}$ midgrass response curves included either a sharply declining exponential curve or a declining logistic curve in which production remained stable until mesquite cover exceeded $30 \%$. In all but the extremely wet year, 2002, $\mathrm{C}_{4}$ midgrass production was almost nonexistent at mesquite cover $>40 \%$. These negative exponential relationships are similar to Walker et al.'s (1972) description of the relationship between herbaceous growth and 


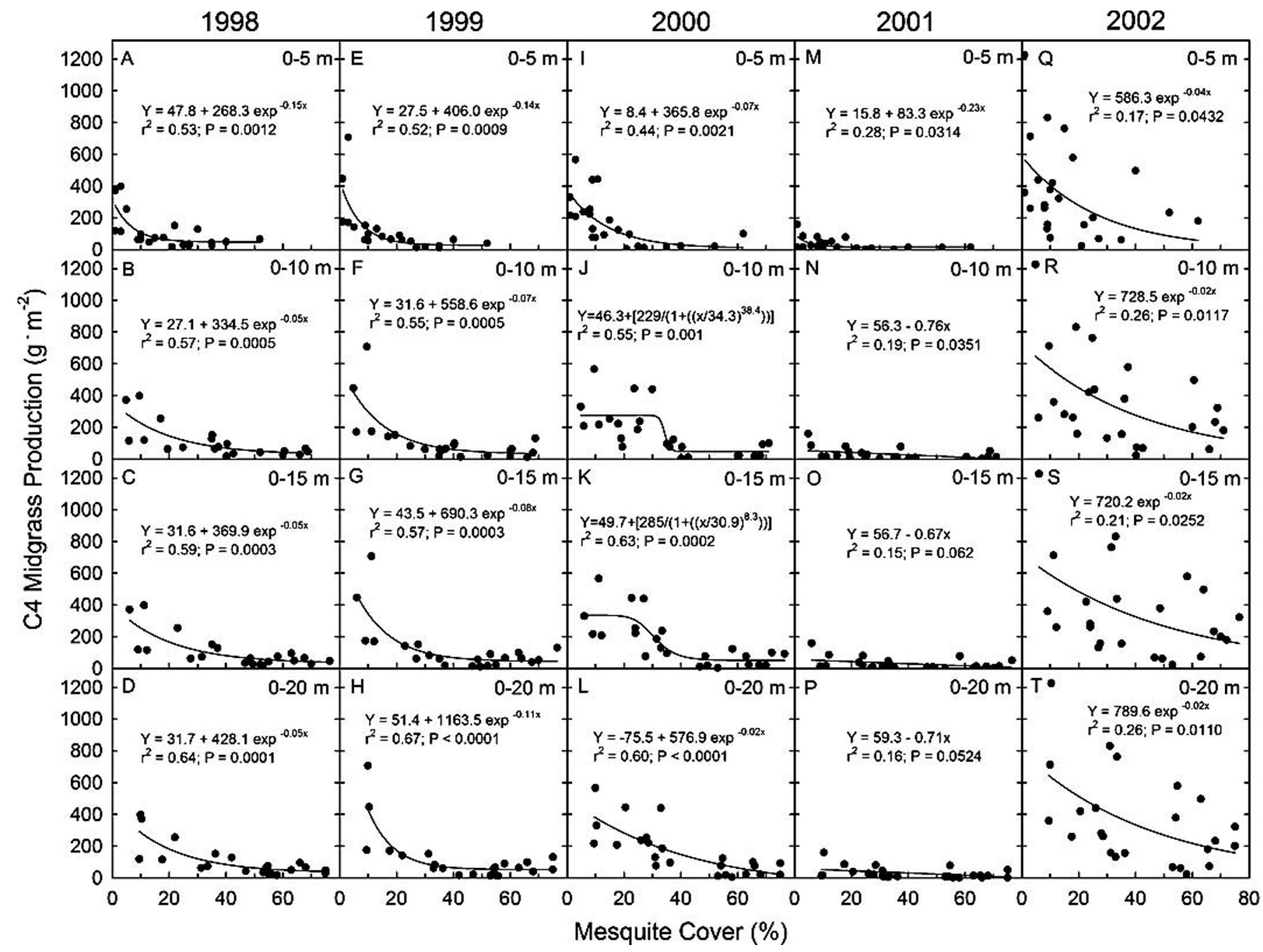

Figure 8. Regression between $\mathrm{C}_{4}$ midgrass production and mesquite percent canopy cover in four land area zones surrounding the grass production point, 1998-2002. Each panel is labeled A-T according to a specific year and land area zone.

Eucalyptus cover in Australia, and Mohamed et al.'s (2011) description of mesquite effects on grass production in southern New Mexico. Our results with $\mathrm{C}_{4}$ midgrasses mostly differ with Ansley et al.'s (2004) description of a reverse logistic relationship where $\mathrm{C}_{4}$ midgrass production did not decline until mesquite cover exceeded $25 \%$. In the current data set, we found such a relationship only in the $0-10$ and $0-15 \mathrm{~m}$ zones in one year (2000). Teague et al. (2008) found mostly declining linear relationships between mesquite cover and $\mathrm{C}_{4}$ midgrass production in a study where livestock grazing was not excluded. We believe the reason they found linear instead of curvilinear relationships was because the enhanced $\mathrm{C}_{4}$ midgrass production at low mesquite cover that would normally cause the curvilinear response curve was eliminated by livestock grazing the $\mathrm{C}_{4}$ midgrasses.

For the most part, $\mathrm{C}_{4}$ shortgrass and $\mathrm{C}_{3}$ midgrass production declined linearly with increasing mesquite cover, but the slopes of these relationships were not steep in most instances, suggesting that these two grass types were not as adversely affected by increasing mesquite cover as were $\mathrm{C}_{4}$ midgrasses. Our $C_{3}$ midgrass results differ from Scifres et al.'s (1982) finding of a quadratic relationship where $\mathrm{C}_{3}$ midgrass production increased under low $(9 \%$ to $30 \%)$ canopy cover of the woody legume, huisache (Acacia farnesiana [L.] Willd.), compared to areas free of huisache, but steadily decreased as huisache cover exceeded $30 \%$ in south Texas. The initial increase in $\mathrm{C}_{3}$ midgrass production was due to the ameliorating effects of the trees on the subcanopy habitat. We did not detect a boost in $\mathrm{C}_{3}$ midgrass production at low mesquite covers (10$30 \%$ ) compared to little or no mesquite cover in any of the years or zones of influence.

\section{Precipitation and Annual Grasses}

The five years of the study experienced marked differences in total annual precipitation, growing season precipitation, and $\mathrm{C}_{3}$ annual grass production. High $\mathrm{C}_{3}$ annual grass production appeared to be triggered by high rainfall during the early spring (April-May) of each year, but especially during May. In the three years that had high annual grass production, two years, 1999 and 2001, had average or above-average rainfall in May, and the greatest annual grass production in this study was associated with the highest May precipitation amount (1999). In the other year of high annual grass growth, 2002, May rainfall was below average, but April precipitation was above 
Table 1. Mean $r^{2}$ and $P$ values ( \pm standard error; $n=3$ or 5 ) for mesquite cover/grass production regressions in four zones of influence averaged over the first three years (1998-2000) and all five years (1998-2002).

\begin{tabular}{|c|c|c|c|c|c|}
\hline \multirow[b]{2}{*}{ Grass type } & \multirow[b]{2}{*}{ Zone } & \multicolumn{2}{|c|}{$3-y r$} & \multicolumn{2}{|c|}{$5-y r$} \\
\hline & & Mean $r^{2}$ & Mean $P$ & Mean $r^{2}$ & Mean $P$ \\
\hline \multirow{3}{*}{$\mathrm{C}_{4}$ shortgrass } & $0-5 \mathrm{~m}$ & $0.33 \pm 0.07$ & $0.009 \pm 0.004$ & $0.26 \pm 0.06$ & $0.024 \pm 0.009$ \\
\hline & $0-15 \mathrm{~m}$ & $0.19 \pm 0.15$ & $0.330 \pm 0.254$ & $0.27 \pm 0.10$ & $0.199 \pm 0.161$ \\
\hline & $0-20 \mathrm{~m}$ & $0.15 \pm 0.14$ & $0.407 \pm 0.215$ & $0.23 \pm 0.09$ & $0.247 \pm 0.153$ \\
\hline \multirow[t]{3}{*}{$\mathrm{C}_{3}$ midgrass } & $0-5 \mathrm{~m}$ & $0.24 \pm 0.04$ & $0.021 \pm 0.011$ & $0.20 \pm 0.05$ & $0.193 \pm 0.174$ \\
\hline & $0-15 \mathrm{~m}$ & $0.48 \pm 0.04$ & $0.0004 \pm 0.0002$ & $0.38 \pm 0.09$ & $0.120 \pm 0.120$ \\
\hline & $0-20 \mathrm{~m}$ & $0.43 \pm 0.05$ & $0.002 \pm 0.001$ & $0.37 \pm 0.10$ & $0.173 \pm 0.172$ \\
\hline \multirow[t]{3}{*}{$\mathrm{C}_{4}$ midgrass } & $0-5 \mathrm{~m}$ & $0.50 \pm 0.03$ & $0.001 \pm 0.000$ & $0.39 \pm 0.07$ & $0.016 \pm 0.009$ \\
\hline & $0-10 \mathrm{~m}$ & $0.56 \pm 0.01$ & $0.001 \pm 0.000$ & $0.42 \pm 0.08$ & $0.010 \pm 0.007$ \\
\hline & $0-15 \mathrm{~m}$ & $0.60 \pm 0.02$ & $0.0003 \pm 0.0000$ & $0.43 \pm 0.10$ & $0.018 \pm 0.012$ \\
\hline & $0-20 \mathrm{~m}$ & $0.06 \pm 0.05$ & $0.512 \pm 0.245$ & $0.05 \pm 0.03$ & $0.509 \pm 0.175$ \\
\hline
\end{tabular}

average. In contrast, April and May precipitation were average or below average in the two years with low annual grass production, 1998 and 2000.

The years 1999 and 2000 had what might be considered more "average" growing-season precipitation, and the perennial grass responses to mesquite cover in these two years were more typical of what is found in the literature with other species. In relatively open areas (i.e., mesquite cover $<30 \%$ ), $\mathrm{C}_{4}$ midgrass production was more suppressed in 1999 than in 2000 in all four zones of influence even though May and June rainfall was more abundant in 1999 than 2000. This difference was probably related to $\mathrm{C}_{3}$ annual grass production, which was five times greater in 1999 than in 2000, and no doubt

Table 2. Relationship between average distance to nearest trees and production of each grass type (SEE=standard error of estimate). Asterisk indicates significance at $P<0.05$.

\begin{tabular}{lclllr}
\hline Grass type & Year & \multicolumn{1}{c}{ Equation } & \multicolumn{1}{c}{$r^{2}$} & $P$ value & \multicolumn{1}{c}{ SEE } \\
\hline $\mathrm{C}_{4}$ shortgrass & 1998 & $Y=-3.23+9.61 x$ & 0.36 & $0.0048^{*}$ & 13.75 \\
& 1999 & $Y=10.52+7.96 x$ & 0.21 & $0.0428^{*}$ & 16.80 \\
& 2000 & $Y=29.3+6.2 x$ & 0.14 & 0.0698 & 15.74 \\
& 2001 & $Y=-3.71+3.09 x$ & 0.23 & $0.0182^{\star}$ & 5.86 \\
& 2002 & $Y=22.8+11.85 x$ & 0.09 & 0.15 & 37.96 \\
$\mathrm{C}_{3}$ midgrass & 1998 & $Y=47.37+6.25 x$ & 0.24 & $0.0323^{\star}$ & 20.97 \\
& 1999 & $Y=56.83+12.6 x$ & 0.29 & $0.0169^{\star}$ & 37.24 \\
& 2000 & $Y=52.78+6.61 x$ & 0.15 & 0.0582 & 27.23 \\
& 2001 & $Y=3.21+1.99 x$ & 0.32 & $0.0032^{\star}$ & 4.96 \\
$\mathrm{C}_{4}$ midgrass & 1998 & $Y=14.21+21.41 x$ & 0.11 & 0.20 & 111.37 \\
& 1999 & $Y=7.45+31.55 x$ & 0.10 & 0.21 & 172.97 \\
& 2000 & $Y=71.98+22.13 x$ & 0.05 & 0.28 & 152.01 \\
& 2001 & $Y=-25.22+13.05 x$ & 0.30 & $0.0054^{*}$ & 32.18 \\
& 2002 & $Y=58.83+71.22 x$ & 0.15 & 0.0604 & 273.72 \\
\hline
\end{tabular}

suppressed $\mathrm{C}_{4}$ midgrass production in a year in which the elevated May/June precipitation pattern should have caused high production in this perennial grass type in areas with lower mesquite cover. The mechanism of suppression by annual grasses was likely two-pronged: (1) depletion of soil moisture in the spring before $\mathrm{C}_{4}$ midgrasses became active; and (2) shading effects in late spring and early summer. The sharply declining exponential curves found for $\mathrm{C}_{4}$ midgrasses in the $0-5-\mathrm{m}$ zone of influence in 1998-1999 almost exactly duplicate in form and absolute values the mesquite cover/grass production relationship found in southern New Mexico (Mohamed et al. 2011). While Mohamed et al. did not separate grass responses by grass type or species, the dominant grasses were a mixture of $\mathrm{C}_{4}$ midand shortgrasses. Laxson et al. (1997) found a significant decrease in mean herbaceous standing crop at mesquite stem densities equivalent to $37-61 \%$ mesquite canopy cover, which also agrees with our $\mathrm{C}_{4}$ midgrasses results.

The tolerance of $\mathrm{C}_{4}$ midgrass production to mesquite cover up to $20-25 \%$ in the year 2000 may have been caused by above-average precipitation in June that stimulated $\mathrm{C}_{4}$ midgrass production in the absence of $\mathrm{C}_{3}$ annual grasses. Of the five years evaluated, the year 2000 was the only year that had low $\mathrm{C}_{3}$ annual grass production coupled with above-average June precipitation. These two factors apparently allowed $\mathrm{C}_{4}$ midgrass production to increase in areas that had low and moderate mesquite cover, causing a logistic function in some zones. However, any mesquite cover that was $>40 \%$ still retained the strong suppression effect it had shown in 1998 and 1999. Thus, some of the data from the year 2000 differ from the declining exponential cover/grass production curve presented by Ansley and Castellano (2006) and Mohamed et al. (2011) and agree with data presented by Ansley et al. (2004).

The two final years of the study, 2001 and 2002, were viewed as extremely atypical for several reasons. Regarding 2001, high $\mathrm{C}_{3}$ annual grass production from average May rainfall, coupled with virtually no precipitation in April, June, 
and July lowered perennial grass production to such a degree that the effects of mesquite cover on perennial grass production became negligible, especially for $\mathrm{C}_{3}$ midgrasses.

Regarding 2002, the mesquite cover and grass production curves were not as well defined in this year compared to the other years. This was especially true for the $\mathrm{C}_{4}$ midgrasses. Some of the GPPs had extremely high production values, probably in response to the very atypically high rainfall of 180 $\mathrm{mm}$ that occurred in July of that year. In the 60 years between 1951 and 2010, there were only four years, 1958, 1991, 2002, and 2010 where July precipitation exceeded $150 \mathrm{~mm}$, and only five other years where it exceeded $100 \mathrm{~mm}$ (NOAA-NCDC 1951-2010). In 40 of those 60 years, July precipitation was below $50 \mathrm{~mm}$. Thus, 2002 clearly represented a rare episodic rainfall period for July, and such high rainfall stimulated growth in some of the $\mathrm{C}_{4}$ midgrass GPPs to such an extent that it overcame the competitive effects of high mesquite cover. We are uncertain why a few GPPs (about 4 or 5 depending on the zone) that were located where mesquite cover was $>30 \%$ had high production, while most of the others (about 11 or 12) did not in 2002. These differences were not related to species. The net result is that the scatter plots in 2002 (Figs. 8Q-8T) appear to be double-tiered, with one set of points in a declining row positioned above another set.

The high rain in July 2002 also stimulated growth of the other grass types and shifted the mesquite cover/grass production curve of the $\mathrm{C}_{3}$ midgrass type toward resembling that of $\mathrm{C}_{4}$ midgrasses in a normal year where growth was sharply reduced at high mesquite cover. Thus, the July rains triggered growth in a grass type that normally does not directly compete with mesquite for water and light due to an "avoidance" strategy based on phenology. Under direct competition, $\mathrm{C}_{3}$ midgrass sensitivity to increasing mesquite cover resembled that of $\mathrm{C}_{4}$ midgrasses.

\section{Indicators of Community Species Dynamics}

Variations in the relationship between mesquite cover and production in each grass type within different lateral zones radiating away from each GPP provides an indirect indication of the transitions in grass community composition that are occurring at the site in response to increasing mesquite encroachment. The mesquite treatments applied 10, 20, or 35 years earlier likely stimulated growth of $\mathrm{C}_{4}$ midgrasses over the other grass types (Ansley and Castellano 2006; Ansley et al. 2010). As mesquite re-established dominance, either through resprouting from trees that were top-killed by the herbicide treatments, or via recruitment of new seedlings from seed, the steady increase of mesquite density and cover combined with the long-term moderate continuous cattle grazing likely began to diminish the frequency of $\mathrm{C}_{4}$ midgrass patches in favor of $\mathrm{C}_{3}$ midgrasses and $\mathrm{C}_{4}$ shortgrasses (Archer 1990).

When we initially located the GPPs, we based our selection on only two criteria: first, that the patch had to be nearly a monoculture of one of the three perennial grass types we were targeting, and second, that the patch had to occur in a gap between mesquite canopies. We did not examine the sizes of each intercanopy gap or mesquite cover within the different zones of influence until after the grass plot sites were selected. It was only after obtaining the nearest neighbor and mesquite canopy cover classification data that we realized that the distance-to-nearest tree was slightly longer, the size of the nearest mesquite was slightly smaller, and mesquite canopy cover within the $0-5$ and $0-10 \mathrm{~m}$ zones were lower in the $\mathrm{C}_{4}$ midgrass GPPs compared to the other grass types. In fact, there appeared to be a gradient of decreasing patch size and increasing mesquite tree size from $\mathrm{C}_{4}$ midgrass to $\mathrm{C}_{3}$ midgrass to $\mathrm{C}_{4}$ shortgrass as revealed both from the distance and mesquite cover data (Figs. 3 and 4).

These differences are indirect evidence of a shift in grass species composition that has occurred at this site as a result of mesquite encroachment. As mesquite density and size increased and gap size between trees decreased, the $\mathrm{C}_{4}$ midgrass patches began to be replaced by $\mathrm{C}_{3}$ midgrasses and $\mathrm{C}_{4}$ shortgrasses. Under this process, we would expect that any remaining $\mathrm{C}_{4}$ midgrass patches would be found in more open intercanopy gaps than what is found in the other grass types. Thus, in our initial selection process, the $\mathrm{C}_{4}$ midgrass sample points that were found and identified may have been located within the few remnant patches of $\mathrm{C}_{4}$ midgrasses that remained where mesquite encroachment was not quite as advanced as elsewhere. These differences were not visually obvious to us and were only revealed after data collection.

\section{MANAGEMENT IMPLICATIONS}

This study illustrates the complexity of the woody cover/grass production relationship from year to year in savanna/woodland ecosystems and suggests that a suite of equations may be necessary to adequately represent such a relationship for a particular rangeland ecosystem. In a mesquite/mixed grass savanna, factors that affect this relationship include, but are not limited to: (1) the amount of land area surrounding a grass production point from which mesquite cover values are determined, (2) the grass type or species, (3) annual precipitation amount and pattern, and (4) the degree of invasive annual grass production. Any sampling procedures should consider determining grass responses at the species or functional group level and may require different land areas for different grass species to develop adequate woody cover/ grass production functional relationships for each grass species or group. Remote sensing of aerial or satellite images may be a useful tool in this regard.

This study demonstrated that mesquite negatively affects growth of a range of grass species and types in both wet and drought years, although some grass types are more sensitive than others. The greater sensitivity of $\mathrm{C}_{4}$ midgrasses to increasing woody cover can have significant impacts on overall grass community production because production potential of this grass type far exceeds that of the other perennial grass types in this region when woody plants are absent. While complete eradication of brush is unrealistic, results suggest that strategies that maintain woody cover below $30 \%$ are essential for maintaining productive stands of $\mathrm{C}_{4}$ midgrasses. In addition, the study revealed that rare episodic events such as the abundant precipitation in midsummer 2002 allowed $C_{4}$ midgrass growth to become temporarily decoupled from mesquite cover effects. These may be the most critical times 
for resource managers to implement measures to limit grazing or other activities that may inhibit $\mathrm{C}_{4}$ midgrass recovery.

\section{ACKNOWLEDGMENTS}

The authors wish to thank the W. T. Waggoner Estate, Vernon, Texas, for providing the location for this research. Betty Kramp, David Jones, and David Johansen assisted with data collection.

\section{LITERATURE CITED}

AKAIKE, H. 1973. Information theory and an extension of the maximum likelihood principle. In: B. N. Petrov and F. Csaki (eds). Proceedings of the Second International Symposium on Information Theory; Budapest, Hungary: Akademiai Kiado. p. 267-281.

Ansley, R. J., and M. J. Castellano. 2006. Strategies for savanna restoration in the southern Great Plains: effects of fire and herbicides. Restoration Ecology 14:420-427.

Ansley, R. J., P. W. Jacoby, and G. J. Cuomo. 1990. Water relations of honey mesquite following severing of lateral roots: influence of location and amount of subsurface water. Journal of Range Management 43:436-442.

Ansley, R. J., B. A. Trevino, And P. W. JaCoby. 1998. Intraspecific competition in honey mesquite: leaf and whole plant responses. Journal of Range Management $51: 345-352$.

Ansley, R. J., X. B. Wu, and B. A. Kramp. 2001. Observation: long-term increases in mesquite canopy cover in a north Texas savanna. Journal of Range Management $54: 171-176$

Ansley, R. J., H. T. Wiedemann, M. J. Castellano, and J. E. Slosser. 2006. Herbaceous restoration of juniper dominated grasslands with chaining and fire. Rangeland Ecology \& Management 59:171-178.

Ansley, R. J., T. W. Boutton, M. Mirik, M. J. Castellano, and B. A. Kramp. 2010. Restoration of $\mathrm{C}_{4}$ grasses with seasonal fires in a $\mathrm{C}_{3} / \mathrm{C}_{4}$ grassland invaded by Prosopis glandulosa, a fire-resistant shrub. Applied Vegetation Science 13:520530.

Ansley, R. J., W. R. Teague, W. E. Pinchak, B. A. Kramp, and D. L. Jones. 2004. Longterm grass yields following chemical control of honey mesquite. Journal of Range Management 57:49-57.

ARcGIS [computer program]. 2010. Version 10. Redlands, CA, USA: ESRI Inc.

ARCHER, S. 1990. Development and stability of grass/woody mosaics in a subtropical savanna parkland, Texas, U.S.A. Journal of Biogeography 17:453-462.

Archer, S., D. S. Schimel, and E. A. Holland. 1995. Mechanisms of shrubland expansion: land use, climate or $\mathrm{CO}_{2}$ ? Climatic Change 29:91-99.

Bedunah, D. J., AND R. E. SosebeE. 1984. Forage response of a mesquite-buffalograss community following range rehabilitation. Journal of Range Management 37:483-487.

Bozdogan, H. 1987. Model selection and Akaike's information criterion (AIC): the general theory and its analytical extensions, Psychometrika 52: 345-370.

Burnham, K. P., And D. R. Anderson. 2002. Model selection and multimodel inference: a practical information-theoretic approach. 2nd ed. New York, NY, USA: SpringerVerlag. $488 p$.

Burnham, K. P., and D. R. Anderson. 2004. Multimodel inference: understanding AIC and BIC in model selection. Sociological Methods and Research 33: 261-304.

Dye, K. L., D. N. UeCKeRT, and S. G. Whisenant. 1995. Redberry juniper-herbaceous understory interactions. Journal of Range Management 48:100-107.

Gibeens, R. P., C. H. Herbel, H. L. Morton, W. D. Lindemann, J. A. Ryder-White, D. B. Richman, E. W. Huddleston, W. H. Conley, C. A. Davis, J. A. Reitzel, D. M. Anderson, AND A. GuIAO. 1986. Some impacts of 2, 4, 5-T on a mesquite duneland ecosystem in southern New Mexico: a synthesis. Journal of Range Management 39:320-326.

Grover, H. D., AND H. B. Musick. 1990. Shrubland encroachment in southern New Mexico, USA: and analysis of desertification processes in the American southwest. Climatic Change 17:305-330.
Heaton, C. B., X. B. Wu, and R. J. Ansley. 2003. Herbicides effects on vegetation spatial patterns in a mesquite savanna. Journal of Range Management 56:627633.

Heitschmidt, R. K., R. J. Ansley, S. L. Dowhower, P. W. Jacoby, and D. L. Price. 1988. Some observations from the excavation of honey mesquite root systems. Journal of Range Management 41:227-231.

Hicks, R. A., D. D. Briske, C. A. Call, and R. J. Ansley. 1990. Co-existence of a perennial $\mathrm{C}_{3}$ bunchgrass in a $\mathrm{C}_{4}$ dominated grassland: an evaluation of gas exchange characteristics. Photosynthetica 24:63-74.

Laxson, J. D., W. H. Schacht, AND M. K. Owens. 1997. Above-ground biomass yields at different densities of honey mesquite. Journal of Range Management 50:550 554.

McDaniel, K. C., J. H. Brock, and R. H. HaAs. 1982. Changes in vegetation and grazing capacity following honey mesquite control. Journal of Range Management 35:551-557.

McPherson, G. R., And H. A. Wright. 1990. Effects of cattle grazing and Juniperus pinchotii canopy cover on herb cover and production in western Texas. American Midland Naturalist 123:144-151.

MilleR, R. F., T. J. SVeJcaR, And J. A. Rose. 2000. Impacts of western juniper on plant community composition and structure. Journal of Range Management 53:574585.

MiRIK, M., AND R. J. Ansley. 2012a. Comparison of ground-measured and imageclassified mesquite (Prosopis glandulosa) canopy cover. Rangeland Ecology \& Management 65:85-95.

MiriK, M., AND R. J. ANsLey. 2012b. Utility of satellite and aerial images for quantification of canopy cover and infilling rates of the invasive woody species honey mesquite on rangeland. Remote Sensing 4:1947-1962.

Mohamed, A. H., J. L. Holechek, D. W. Balley, C. L. Campbell, and M. N. Demers. 2011. Mesquite encroachment impact on southern New Mexico rangelands: remote sensing and geographic information systems approach. Journal of Applied Remote Sensing 5:1-11. doi:10.1117/1.3571040

Motulski, H., AND A. Christopoulos. 2003. Fitting models to biological data using linear and nonlinear regression - a practical guide to curve fitting. San Diego, CA, USA: GraphPad Software Inc. 351 p. Available at: http://www.graphpad.com/manuals/ prism4/regressionbook.pdfcom. Accessed 23 July 2013.

[nOAa-nCDC] National Oceanic and Atmospheric Administration, Climatic Data Center. 2011. Air temperature data. Available at: http://www.ncdc.noaa.gov/oa/ncdc. html. Accessed 24 May 2011.

NOAA-NCDC. 1951-2010. Annual reports, 1951-2010. Asheville, NC, USA: NOAA. [USDA-NRCS] United States Department of Agriculture, Natural Resource Conservation Service. 2009. Plants database. Available at: http://plants.usda.gov. Accessed 5 January 2009.

USDA-NRCS. 2011. Soil series descriptions. Available at: http://soils.usda.gov. Accessed 17 August 2011.

Royer, P. D., D. D. Breshears, C. B. Zou, J. C. Villegas, N. S. Cobb, and S. A. Kurc. 2012. Density-dependent ecohydrological effects of Pinon-juniper woody canopy cover on soil microclimate and potential soil evaporation. Rangeland Ecology \& Management 65:11-20.

SAS [SOFtware]. 2002. SAS Version 9.1 for Windows. Cary, NC, USA: SAS Institute, Inc.

SCAnLAN, J. C. 1992. A model of woody-herbaceous biomass relationships in eucalypt and mesquite communities. Journal of Range Management 45:75-80.

Schenk, H. J., AND R. B. JaCkson. 2002. Rooting depths, lateral root spreads and below-ground/above-ground allometries of plants in water-limited ecosystems. Journal of Ecology 90:480-494.

Schlesinger, W. H., J. F. Reynolds, G. L. Cunningham, L. F. Huenneke, W. M. Jarrell, R. A. VIRGinia, AND W. G. Whitford. 1990. Biological feedbacks in global desertification. Science 247:1043-1048.

Scholes, R. J., and S. Archer. 1997. Tree-grass interactions in savannas. Annual Review of Ecology and Systematics 28:517-544.

Scifres, C. J., J. L. Mutz, R. E. Whitson, and D. L. Drawe. 1982. Interrelationships of huisache canopy cover with range forage on the Coastal Prairie. Journal of Range Management 35:558-562.

SigmaPlot and SigmaStat Software [computer program]. 2009. Version 11.0. San Jose, CA, USA: Systat Software Inc. 
Teague, W. R., R. J. Ansley, W. E. Pinchak, S. L. Dowhower, S. A. Gerrard, and J. A. WAGGONER. 2008. Interannual herbaceous biomass response to increasing honey mesquite cover on two soils. Rangeland Ecology \& Management 61:496-508.

Van Auken, 0. W. 2000. Shrub invasions of North American semiarid grasslands. Annual Review of Ecology \& Systematics 31:197-215.

Villegas, J. C., D. D. Breshears, C. B. Zou, and D. J. Law. 2010a. Ecohydrological controls of soil evaporation in deciduous drylands: how the hierarchical effects of litter, patch and vegetation mosaic cover interact with phenology and season. Journal of Arid Environments 74:595-602.

Villegas, J. C., D. D. Breshears, C. B. Zou, and P. D. Royer. 2010b. Seasonally pulsed heterogeneity in microclimate: phenology and cover effects along deciduous grassland-forest continuum. Vadose Zone Journal 9:537-547.

WalkeR, J., R. M. Moore, and J. A. Robertson. 1972. Herbage response to tree and shrub thinning in Eucalyptus populnea shrub woodlands. Australian Journal of Agricultural Research 23:405-410. 